\title{
Szociális ellátások a társadalombiztosítási családtámogatás rendszerében
}

\author{
Szombati Ivett dr. \\ Széchenyi István Egyetem, Egészség- és Sporttudományi Kar, Egészségtudományi Tanszék, Győr
}

Bevezetés és célkitüzés: A tanulmány - a rendszerváltástól napjainkig eltelt időszak adatait vizsgálva - a szociális ellátások közül a gyermekvállalással kapcsolatosan kifizetett és jelenleg az Egészségbiztosítási Alap költségvetésének pénzbeli ellátásokat terhelő részét, annak változásait tekinti át, kiemelt figyelmet fordítva az ellátások változásaira, nemzetközi relációira.

Adatok és módszerek: A kutatás keretében az Egészségbiztosítási Alap, a Központi Statisztikai Hivatal, a Gazdasági Együttmúködési és Fejlesztési Szervezet (OECD) és a Magyar Államkincstár adatainak elemzései és a szakirodalmi áttekintés során a magyar családpolitikai rendszer változásainak rendszerében elhelyezve elemezzük a szociális pénzbeli ellátások ezen csoportját.

Eredmények: A magyar családpolitikát még napjainkban is alapvetően meghatározza a „3 évig otthon a gyerekkel” szemlélet. A gyermekkel otthon töltött hosszú időszak erősen megnehezíti az édesanyák munkaerôpiacról való időleges kilépését, majd visszailleszkedését, ami közvetlen hatást gyakorol a gazdaság termelékenységére. Bár a jelenlegi hazai szabályozás szerint az édesanya a gyermekgondozási díj teljes folyósítása mellett, már a kisgyermek 6 hónapos korától korlátlanul vállalhat munkát, a nyugat-európai országokkal összehasonlítva a részmunkaidős, valamint a távmunkában történő foglalkoztatás még mindig kezdetleges fázisban van. Felmérésünk szerint a magyar családok nagyobb része a gyermek megszületése után közvetlenül a gyermekgondozási segély ellátást veszi igénybe, tehát biztosítási jogviszony nélkül vállal gyermeket, így nem vesz részt a munkaerőpiaci folyamatokban. Amennyiben részt vesz is, még mindig magas a minimálbéren történő foglalkoztatás, ami ahhoz vezetett, hogy 2016-2017-ben a kétgyermekes kétkeresős családok 36\%-a kényszerült a létminimum alatti jövedelemből élni.

Következtetések: A vizsgált időszakban lezajló társadalmi, családpolitikai változások sajnálatos módon annak ellenére sem tudtak kellőképpen reagálni a demográfiai kihívásokra, hogy Magyarország - az európai és az OECD-országokkal összehasonlítva - kiemelkedően sokat költ családpolitikára.

Orv Hetil. 2019; 160(Suppl 1): 43-48.

Kulcsszavak: szociális pénzbeli ellátások, egészségügyi ellátórendszer

\section{Social services in the social security system of family support}

Introduction and aim: In my study, analysing the data available from the change of the regime to the present day, from among the social services, I examine the changes of the financial support relating to children and its parts which are currently financed from the budget of the National Health Insurance Fund of Hungary, with special emphasis on the Child Care Benefit and the Child Care Allowance and their modifications.

Data and methods: Within the framework of our research, we analyze - through data from the National Health Insurance Fund of Hungary, the Hungarian Central Statistical Office, the Organisation for Economic Co-operation and Development (OECD) and the Hungarian State Treasury as well as on the basis of literature review - the social financial support and its changes, within the family policy system.

Results: Hungarian family policy is still driven by the attitude of staying at home for three years with the child. The long period spent at home with the children fundamentally affects the adjustment of mothers to the labour market which has a direct effect on the economic productivity. Even though according to the current regulations, mothers are allowed to work full-time besides receiving child care allowance after their child fills 6 months, part-time employment and telework is still in its infancy compared to the Western-European countries. Based on our research, high percentage of families go for the child care benefit directly after the birth of the child thus not participating in the labour market processes. Besides if they do participate, the percentage of employment on minimal wage is still very high which means that in 2016-2017 36\% of families with two breadwinners and two children were forced to survive on subsistence income. 
Conclusion: In the examined period, we found that social and family policy changes unfortunately were not able to react sufficiently to the demographic challenges despite Hungary spending significantly more on family policy than other European and OECD countries.

Keywords: social financial services, health care system

Szombati I. [Social services in the social security system of family support]. Orv Hetil. 2019; 160(Suppl 1): 43-48.

\section{Rövidítések}

CSED = csecsemőgondozási díj; E. Alap = Egészségbiztosítási Alap; GDP $=$ (gross domestic product) bruttó hazai termék; GYED = gyermekgondozási díj; GYES = gyermekgondozási segély; GYET = gyermeknevelési támogatás; KSH = Központi Statisztikai Hivatal; OECD = $($ Organisation for Economic Cooperation and Development) Gazdasági Együttmúködési és Fejlesztési Szervezet; TGYS = terhességi-gyermekágyi segély

A szülés utáni szociális ellátások tekintetében óriási különbségek vannak az egyes országokban, mint ahogy az egészségügyi ellátórendszerek szerkezete és financiális háttere is nagyon barázdált és sokrétű, akárcsak az európai ellátórendszerek vizsgálatának fényében. Van olyan ország, ahol akár három évig otthon maradhatnak az anyák, van, ahol az apák is hónapokig tartó fizetett kimenőt kapnak, és van a Gazdasági Együttmúködési és Fejlesztési Szervezetnek (OECD) egy országa, ahol nincs fizetett távollét. Egy 2016-os, a Pénzügyi Szemlében közzétett kutatás szerint Magyarország minden ellátástípus tekintetében az élvonalban végzett. Szociális ellátórendszerünknek ez a területe erôs, az ellátórendszerrel szemben megfogalmazott kritikák nem ezt a területet célozzák, egészségügyi ellátórendszerünknek tehát van olyan része, amely a nyugat-európai színvonalat eléri, sőt bizonyos szempontból túlszárnyalja; persze ennek vannak negatív következményei a munkaerőpiac területén [1-5]. A szülés utáni, munkaerőpiacra történő visszatérés útja hazánkban sokkal rögösebb, mint Európa nyugati országaiban, és demográfiai mutatóink sem hozzák a várt eredményeket [6-10].

A gyermekvállalással kapcsolatosan kifizetett támogatások fedezete jelenleg az Egészségbiztosítási Alap (E. Alap) költségvetésének pénzbeli ellátásokat terhelő fejezetében van. Az E. Alap költségvetésének egyéb fejezeteit, a hazai egészségügyi rendszer felépítését [11-15], múködését [16-19] és finanszírozásának további részleteit [20-23] számos tanulmány érintette, ugyanakkor a szociális ellátások körébe soroltak kevésbé vannak feldolgozva.

A jelen áttekintő tanulmányban a rendszerváltástól napjainkig eltelt időszak adatait vizsgálva a szociális ellátások közül a gyermekvállalással kapcsolatosan kifizetett és jelenleg az E. Alap költségvetésének pénzbeli ellátásokat terhelő részét, annak változásait tekintjük át, kiemelt figyelmet fordítva az ellátások változásaira, nemzetközi relációira.

\section{Demográfiai helyzet Magyarországon}

Hazánkban a születések száma 1975-ben érte el maximumát, amikor 194240 újszülött jött a világra. A lakosságszám pedig 1980-ban 10709000 lakossal érte el csúcspontját. A születések száma és az ország lakosságszáma azóta csökkenő tendenciát mutat (1. ábra).

A születések száma 2017-ben 1,6\%-kal elmaradt az előzó évitől, a halálozásoké pedig 3,7\%-kal meghaladta azt a Központi Statisztikai Hivatal (KSH) 2018 elején közölt adatai szerint. A természetes fogyás 2017-ben 40100 fó volt, 6110-zel több, mint egy évvel korábban. 2017 decemberében a születések száma 2,9\%-kal, a halálozásoké pedig 4,3\%-kal kevesebb volt, mint az előző év azonos hónapjában. Az év utolsó hónapjában a természetes fogyás 3895 fó volt, 291-gyel kevesebb a 2016. decemberinél. 2017 utolsó hónapjában 7603 gyermek született, ami 2,9\%-kal, 229-cel elmaradt a 2016. decemberitől. Az elhunytak száma 2017 végén 11498 fö volt, 4,3\%-kal, 520-szal kevesebb az előzó év decemberinél. A születések száma kisebb arányban csökkent, mint a halálozásoké, ennek következtében a természetes fogyás a 2016. decemberi 4186-hoz képest 7\%-ot mérséklődve 3895 fö volt $[24,25]$.

Magyarországon jelenleg valamivel rosszabb a termékenységi mutató, mint az európai uniós átlag. A magyar nők a legfrissebb adatok szerint 1,5 gyereket szülnek életük során, míg az uniós tagállamokban átlagosan 1,57et. Nem reális, hogy 2030-ra a magyarországi termékenységi mutató elérje a célként kitűzött kettőt.

A termékenységi arányszám (vagyis annak mutatója, hogy a nők átlagosan hány gyereket vállalnak Magyarországon) mélypontja 2011-ben volt, 1,24, ezt mostanra 1,5-re sikerült feltornászni. Ezzel az Európai Unió egyik legrosszabbul teljesítő országából a középmezőnybe kerültünk. A tényekhez tartozik, hogy hazánkban a potenciális gyerekvállalók száma rendkívül gyorsan csökken, évről évre 30 ezerrel kevesebb szülőképes korú nő él Magyarországon, és ebben a kivándorlási adatok nincsenek benne [26].

Ahhoz, hogy valóban fenntartható legyen az ország demográfiai helyzete, négy alapvető dologra van szükség, és ennek csak egyik pontja a gyermekvállalási arány növelése. Nagyon fontos az egészségügyre fordított öszszeg és a várható élettartam növelése, a kivándorlást kezelő szakpolitika kialakítása és végül, de nem utolsósorban megfelelő álláspont kialakítása a bevándorlásról is. A jelen helyzetben demográfiai okokból mindenképpen 


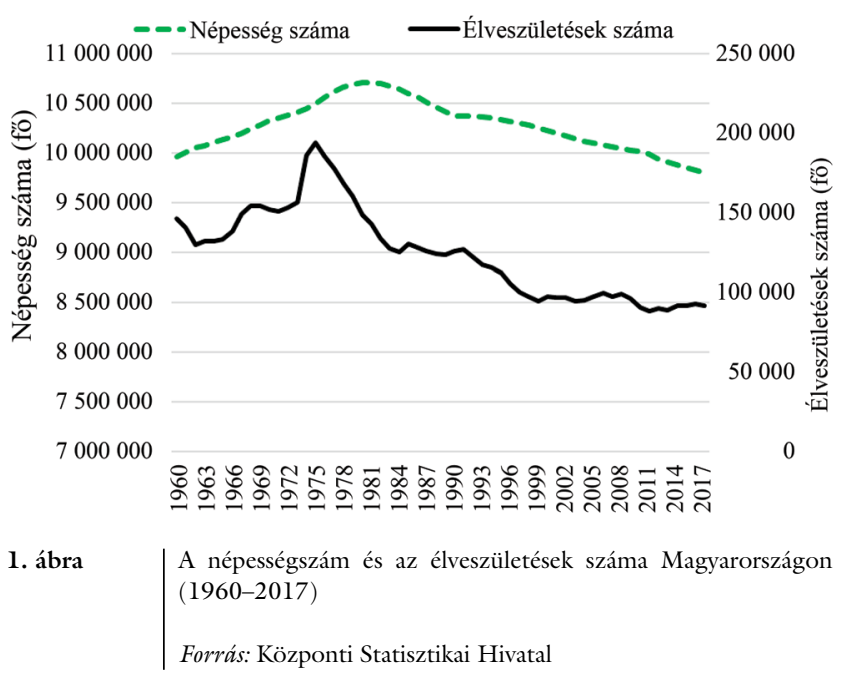

szükség van bevándorlási többletre. Ha mindezeket a szempontokat sikerülne teljesíteni, akár 1,7-1,8-as termékenységi mutató mellett is stabilizálódhatna az ország lélekszáma [27].

Magyarországon - Semmelweis Ignác nemzetközileg is nagyra értékelt munkásságának tükrében [28, 29] különös jelentősége van a gyermekvállalással kapcsolatos kérdéseknek. A női egészségvédelem érdekében számos egészségpolitikai intézkedés történt a nőgyógyászati szakterületen, kiemelendő a nőgyógyászati szűrővizsgálatok további fejlesztését [30-36].

\section{Családtámogatási környezet a nemzetközi gyakorlatban}

A magyar családtámogatási rendszer mintegy húsz különböző ellátásból áll. Ezek egyik célja a gyermeknevelés anyagi terheinek csökkentése pénzbeli vagy természetbeni juttatásokkal, mint a csecsemőgondozási díj (CSED), a gyermekgondozási díj (GYED), a gyermekgondozási segély (GYES), a gyermeknevelési támogatás (GYET), illetve a szociális alapon igénybe vehető ellátások

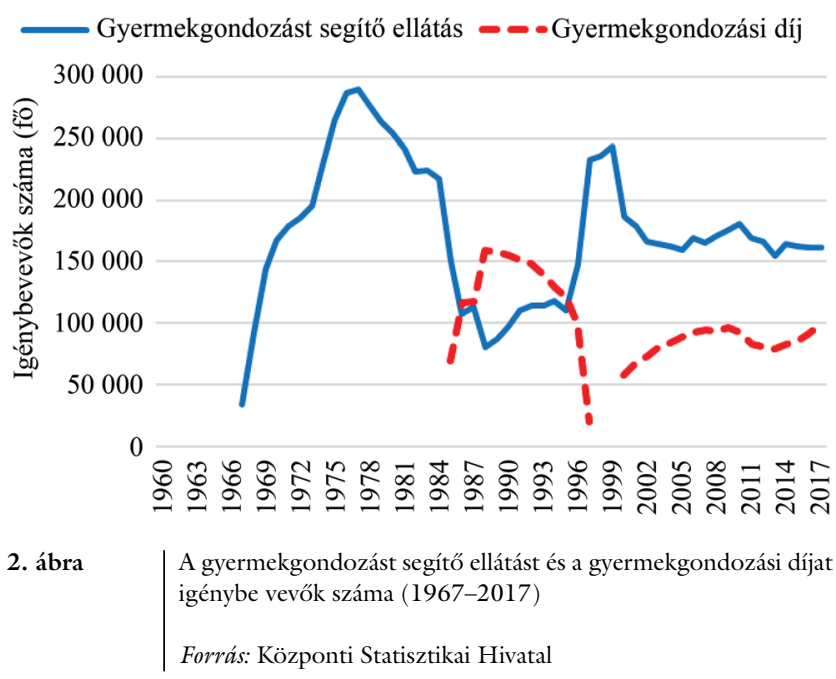

(2. ábra). Az ellátási rendszer másik célja a családok mindennapjainak megkönnyítése: például pótszabadság munkavállaló szülők számára, gyermekápolási táppénz a beteg gyermek gondozására.

$\mathrm{Az}$ ellátások rendszerét érintő módosítások elsősorban, de nem kizárólag, a háromévesnél fiatalabb gyermeket nevelő családokat érintik, és a kisgyermek melletti munkavállalás ösztönzését próbálják segíteni. A magyar rendszer jellegzetessége, hogy a családok - anyagi helyzetüktől függetlenül - három éven keresztül mind részesülhetnek valamilyen pénzbeli juttatásban [37]. Ez a legtöbb európai, nyugat-európai országban nem így van, az anyagi támogatások a legtöbb országban előzetes munkaviszonyhoz kötöttek, akkor járnak, ha a szülő a gyermek születése előtt aktív keresőként részt vett a munkaerőpiacon, és gyermeke születésének idejére fizetés nélküli szabadságot vesz ki. A legtöbb országban még ebben az esetben is csak néhány hónapig folyósítható így ellátás, Belgiumban 3 hónapig, Franciaországban 6 hónapig, a skandináv országokban legfeljebb l évig; ezáltal máris érezhető az a számottevő rendszerszintű különbség, hogy a nyugat-európai országokban az édesanyák erősen ösztönözve vannak a mielőbbi munkaerőpiaci visszatérésre, aminek szociológiai, társadalmi, pszichés hatásai külön elemzés tárgyát képezhetnék, de a gazdasági termelékenységre gyakorolt pozitív hatás vitathatatlan [38].

Magyarország európai viszonylatban sokat költ a családokra. A szúk értelemben vett családtámogatási kiadásokra a magyar állam 2006 óta stabilan a GDP 2\% körüli összegét költi. Az OECD a nemzetközi elemzéseiben a családpolitikára jutó kiadásokat tágabban értelmezi, a pénzbeli ellátásokhoz hozzáveszi a „szolgáltatásokat”, melyek a kisgyermekek nappali ellátására fordított kiadásokat takarják, másrészt az adórendszeren keresztül juttatott kedvezményeket. Az így számított családpolitikára szánt kiadások a GDP arányában Európa-szinten nagy szórást mutatnak. A legtöbbet az Egyesült Királyságban költenek ilyen kiadásokra, a GDP 4,6\%-át, míg a legkevesebbet a dél-európai államokban (például Görögország), ahol 1,4\%-ot költenek ilyen juttatásokra [39, 40].

Magyarországon ez az arány igen magas, az OECD viszonylatában 4\%. A gyermekgondozást segítő ellátás és a gyermekgondozási díj havi egy fơre jutó átlagos összege 1990 és 2017 között egyenletesen növekedett (3. ábra), illetve a csecsemőgondozási díjra (CSED), a terhességi-gyermekágyi segélyre (TGYS) és a gyermekgondozási díjra fordított éves kifizetések összege 19952016-ban ugyancsak egyenletesen emelkedő tendenciát mutat (4. ábra).

Ehhez képest demográfiai mutatóink sajnos nem hoznak jobb eredményt az elmúlt évtizedben. Viszont ezzel az arányszámmal olyan nyugat-európai államokat utasítunk magunk mögé, mint például Németország, Ausztria vagy Franciaország. Franciaország egyébként is kivételes olyan szempontból, hogy a szolgáltatásokra költik a családokra fordított kiadások nagyobb részét, míg pénz- 


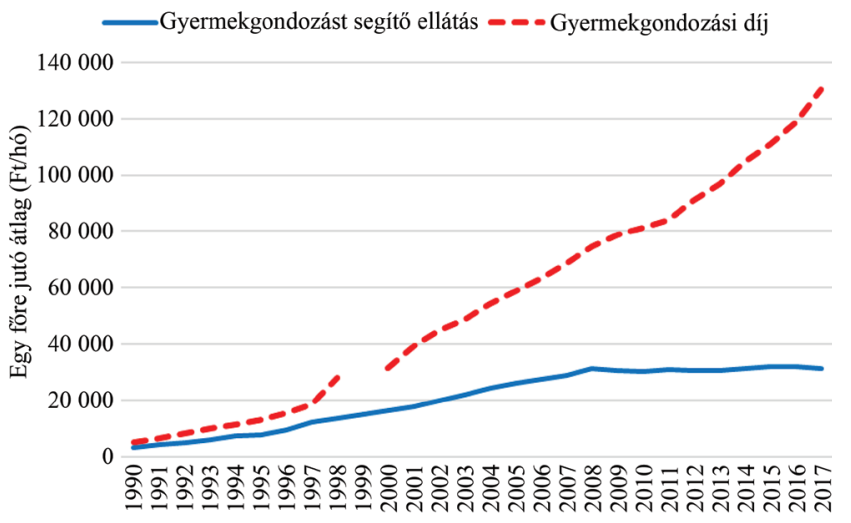

3. ábra $\mid$ A gyermekgondozást segítő ellátás és a gyermekgondozási díj havi átlagos összege (1990-2017)

Forrás: Központi Statisztikai Hivatal

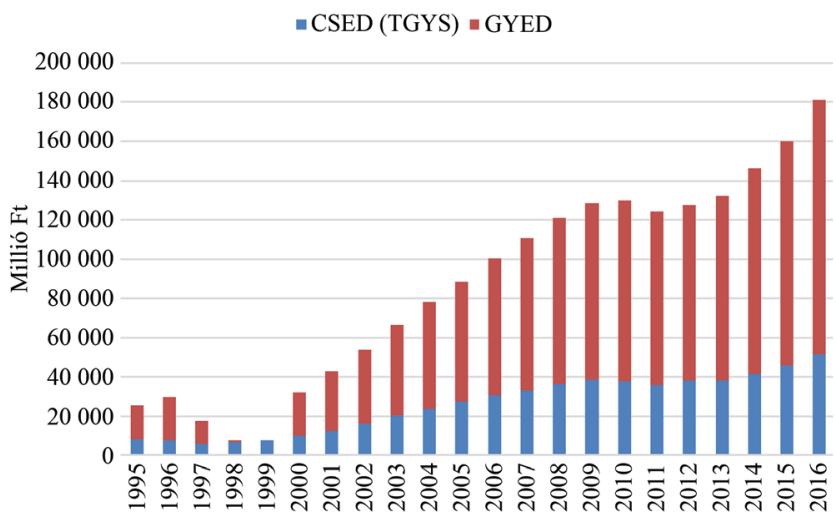

4. ábra munkavállalásának elősegítése, hiszen hazánkban még napjainkban is nagyon alacsony a három éven aluli gyermeket nevelő anyák foglalkoztatottsága. Magyarországon alapvetően a kétkeresős családmodell a jellemző, vagyis a nők részvétele a munkaerőpiacon ugyanannyira jelen van, mint a férfiaké. Ugyanakkor a kisgyermekes anyák több gyermek vállalása esetén több, akár 6-8 évre is elhagyják a munkaerópiacot, ami egyenes arányosan azt eredményezi, hogy a nők foglalkoztatási rátája ebben az életkorban jóval alacsonyabb, mint a férfiaké. Az anyák „lemaradását” elsősorban a három éven aluli gyermeket nevelők alacsony foglalkoztatottsága okozza, mely bár folyamatosan emelkedik, hazánkban a legalacsonyabb az Európai Unióban, mindössze 6-7\%. Egyes európai országokban ez a 70\%-ot is meghaladja.

A rendszer részeként a családi adókedvezmény kiszélesítése nóvum, Európa-szerte ez a családtámogatási rendszer leggyengébb eleme; ehhez képest sokkal nagyobb összeget költenek az országok pénzügyi juttatásokra, valamint szolgáltatásokra. Emellett új támogatásként 2014. január 1. napjától bevezetésre került a GYED Extra, amely négy fóelemet tartalmaz: 1) több ellátás folyósítása egyidejűleg, 2) a munkavállalás lehetősége nevelési ellátás folyósítása mellett: a gyermek 1 éves - mára féléves - kora után GYED, illetve GYES folyósítása esetén időkorlátozás nélkül lehet munkát vállalni a jogosultság megtartása mellett; 3 ) a GYED-re jogosultság ikrek esetében egy évvel meghosszabbodik; 4) diplomásGYED bevezetése: a felsőfokú tanulmányok folytatása alatt vagy azok befejezését követő egy éven belül szülő kismamának is jár fix összegú GYED.

\section{Következtetés}

Az európai és észak-amerikai fejlett társadalmak számára komoly kihívást jelent a népességszám csökkenése. A kormányzati szereplők részéről különböző megoldási stratégiák bontakoztak ki a probléma kezelésére. Egyes országokban a csökkenő népességszámot kívülről érkező bevándorlók segítségével próbálják megállítani (migrációs megközelítés). Más országokban a gyermekvállalást ösztönző társadalmi és munkahelyi környezetnek, a családtámogatási rendszereknek az átalakítása kap hangsúlyt (családtámogatási megközelítés).

Hazánkban jelentős kormányzati intézkedések történtek az elmúlt években a születésszám emelése, a családok gyermekvállalási hajlandóságának fokozása érdekében.

Anyagi támogatás: A közlemény a Magyar Nemzeti Bank Pallas Athéné Innovációs és Geopolitikai Alapítványának (PAIGEO) pályázati támogatásával készült, „A pénzbeli és természetbeni ellátások arányai az Egészségbiztositási Alap költségvetésében a munkaeröpiaci folyamatok tükrében” címú 26/2017. (05. 12.) kuratóriumihatározat-számú projekt keretében. 
A szerző a cikk végleges változatát elolvasta és jóváhagyta.

Érdekeltségek: A szerzőnek nincsenek érdekeltségei.

\section{Irodalom}

[1] Gellérné Lukács É, Gyeney L, Kovács G, et al. Third-country nationals in the Hungarian public health care sector. New Med. 2015; 19: 29-36.

[2] Boncz I, Kaló Z, Mohamed Ibrahim MIB, et al. Further steps in the development of pharmacoeconomics, outcomes research, and health technology assessment in Central and Eastern Europe, Western Asia, and Africa. Value Health Reg Issues 2013; 2: 169170.

[3] Cserháti P, Laczkó T, Vendégh Zs, et al. Problems of rehabilitation in our country and the possibilities of its further development in cases of hip fractures. [A combnyaktáji törés utáni rehabilitáció hazai problémái és a fejlesztés lehetőségei.] Magy Traumatol. 1992; 35: 149-154. [Hungarian]

[4] Kovács G. The basics of the health care system. In: Kovács G, Nogel M, Fáskerty É. Health and social rights. [Az egészségügyi ellátórendszer alapjai. In: Kovács $G$, Nogel M, Fáskerty É. Egészségügyi és szociális jog.] Universitas-Győrr Nonprofit Kft., Győr, 2017; pp. 120-133. [Hungarian]

[5] Vajda R, Juhász K, Endrei D. Clinical and health policy experiences with HPV prevalence within the Hungarian organized cervical cancer screening program. J Gynecol Oncol. 2018; 29: e45.

[6] Kovács G. The basics of the health care system. In: Kovács G, Nogel M, Fáskerty É. Health and social rights handbook. [Az egészségügyi ellátórendszer alapjai. In: Kovács G, Nogel $M$, Fáskerty É. Egészségügyi és szociális jogi kézikönyv.] UniversitasGyőr Nonprofit Kft., 2017; pp. 314-338. [Hungarian]

[7] Kovács G, Nogel M. Activity of forensic experts and quality assurance in Hungary. Forensic Sci Int. 2017; 277: 257-258.

[8] Kovács G. Data protection on health care: the outline of health care data management. [Adatvédelem az egészségügyben: az egészségügyi adatkezelés vázlata.] Med et Jur. 2011; 2(1): 1618. [Hungarian]

[9] Kovács G. Special issues in health care data protection. [Speciális területek az egészségügyi adatkezelésben.] Med et Jur. 2011; 2(3): 14-17. [Hungarian]

[10] Kovács G. Sectorial data protection - health care data protection. [Szektorális adatvédelem - egészségügyi adatvédelem.] Med et Jur. 2011; 2(2): 17-19. [Hungarian]

[11] Kovács G, Nogel M, Fáskerty É. Health and social rights handbook. [Egészségügyi és szociális jogi kézikönyv.] UniversitasGyőr Nonprofit Kft., Győr, 2017. [Hungarian]

[12] Kovács G, Nogel M, Fáskerty É. Health and social rights. [Egészségügyi és szociális jog.] Universitas-Győr Nonprofit Kft., Győr, 2017. [Hungarian]

[13] Boncz I, Nagy J, Körösi L, et al. The effect of the introduction of visit fee on the number of patient-visits to outpatient care departments in Hungary. Value Health 2008; 11: A368-A369.

[14] Kovács G. Professional requirements for health care services. In: Kovács G, Nogel M, Fáskerty É. Health and social rights. [Az egészségügyi szolgáltatások szakmai követelményei. In: Kovács G, Nogel M, Fáskerty É. Egészségügyi és szociális jog.] Universitas-Győr Nonprofit Kft., Győr, 2017; pp. 134-137. [Hungarian]

[15] Boncz I, Dózsa C, Kaló Z, et al. Development of health economics in Hungary between 1990-2006. Eur J Health Econ. 2006; 7(Suppl 1): S4-S6.

[16] Boncz I, Evetovits T, Dózsa Cs, et al. The Hungarian Care Managing Organization Pilot Program. Value Health Reg Issues $2015 ; 7: 27-33$.
[17] Endrei D, Molics B, Ágoston I. Multicriteria decision analysis in the reimbursement of new medical technologies: real-world experiences from Hungary. Value Health 2014; 17: 487-489.

[18] Inotai A, Nguyen HT, Hidayat B, et al. Guidance toward the implementation of multicriteria decision analysis framework in developing countries. Expert Rev Pharmacoecon Outcomes Res. 2018; 18: 585-592.

[19] Csanádi M, Löblová O, Ozierański P, et al. When health technology assessment is confidential and experts have no power: the case of Hungary. Health Econ Policy Law 2018 Mar 26. doi: $10.1017 /$ S1744133118000051. [Epub ahead of print]

[20] Financing of health care services in Hungary. Eur J Health Econ. 2004; 5: 252-258.

[21] Boncz I, Sebestyén A. Financial deficits in the health services of the UK and Hungary. Lancet 2006; 368: 917-918.

[22] Greenberg D, Mohamed Ibrahim MIB, Boncz I. What are the challenges in conducting cost-of-illness studies? Value Health Reg Issues 2014; 4: 115-116.

[23] Cserháti P, Laczkó T, Flóris I, et al. Evaluation of the treatment and rehabilitation of hip fractures by SAHFE European project. [A csípőtáji törések kezelésének és rehabilitációjának értékelése a SAHFE európai projekt révén.] Rehabilitáció 2010; 20: 96-101. [Hungarian]

[24] Makay Zs, Blaskó Zs. Family support, child rearing, emloyment. In: Öri P, Spéder Zs. (eds.) Demographic portrait - 2012. [Családtámogatás, gyermeknevelés, munkavállalás. In: Öri $\mathrm{P}$, Spéder Zs. (szerk.) Demográfiai portré - 2012.] KSH, Népességtudományi Kutatóintézet, Budapest, 2012; pp. 45-56. [Hungarian]

[25] Endrei D, Sebestyén A, Gazsó T, et al. Financing of gynecological care. [A szülészeti-nőgyógyászati ellátás finanszírozási kérdései.] Magy Nőorv L. 2016; 79: 78-81. [Hungarian]

[26] Gábos A. The fertility effects of the Hungarian family support system. Doctoral dissertation. [A magyar családtámogatási rendszer termékenységi hatásai. Doktori disszertáció.] Corvinus Egyetem, Szociológia Doktori Iskola, Budapest, 2018. Available from: http://phd.lib.uni-corvinus.hu/79/1/gabos_andras.pdf [Hungarian].

[27] Földházi E. The projected population development of Hungary until 2060 - with special attention to international migration. [Magyarország népességének várható alakulása 2060-ig - különös tekintettel a nemzetközi vándorlásra.] Demográfia 2014; 57: 241-269. [Hungarian]

[28] Papp Z. Recollection of the great predecessor by a late successor leader. [Semmelweis Ignác kései tanszékvezetői utódjának megemlékezése.] Orv Hetil. 2018; 159: 1071-1078. [Hungarian]

[29] Papp Z. Ignác Semmelweis, the Hungarian icon of perinatology was born 200 years ago. [200 éve született Semmelweis Ignác, a modern perinatológia magyar ikonja.] Orv Hetil. 2018; 159: 1039-1040. [Hungarian]

[30] Vajda R, Árváné Egri Cs, Kovács A, et al. Assessment of the pilot program for cervical cancer screening by health visitors. [A védőnői méhnyakszúrési pilotprogram értékelése.] Orv Hetil. 2017; 158: 461-467. [Hungarian]

[31] Koiss R, Boncz I, Hernádi Z, et al. Proposal for the modernization of cervical screening procedure in Hungary. [Javaslat a hazai méhnyakszürési eljárásrend korszerüsítésére.] Orv Hetil. 2017; 158: 2062-2067. [Hungarian]

[32] Endrei D, Zemplényi A, Molics B, et al. The effect of performance-volume limit on the DRG based acute care hospital financing in Hungary. Health Policy 2014; 115: 152-156.

[33] Boncz I, Sebestyén A, Pál M, et al. Health economics analysis of cervical cancer screening. [A méhnyakrákszưrések egészség-gazdaságtani elemzése.] Orv Hetil. 2003; 144: 713-717.

[34] Boncz I, Sebestyén A, Döbrőssy L, et al. The coverage of cervical screening in Hungary. [A méhnyakszúrés részvételi mutatói Magyarországon.] Orv Hetil. 2007; 148: 2177-2182. 
[35] Boncz I. Prevention of cervical cancer in low-resource settings. JAMA 2006; 295: 1248.

[36] Kívés Z, Juhász K, Csákvári T, et al. Cancer screening policy in Hungary. Int J Cancer 2018; 143: 1003-1004.

[37] Gábos A, Tóth IGy, et al. The economic motives and effects of supporting childbirth. In: Cseh-Szombathy L, Tóth PP. (eds.) Population and population policy. [A gyermekvállalás támogatásának gazdasági motívumai és hatásai. In: Cseh-Szombathy L, Tóth PP. (szerk.) Népesedés és népesedéspolitika.] Századvég Kiadó, Budapest, 2001; p. 125. [Hungarian]

[38] Kovács G. Maternal aspects or fear of legal consequences. [Anyai szempontok, vagy a következményektől való félelem?] Med et Jur. 2016; 7(2): 24-30. [Hungarian]

[39] Social Expenditure Update 2016. Social spending stays at historically high levels in many OECD countries. OECD, Paris, 2016.
[40] Bennett J. Benchmarks for 'Early childhood services in OECD countries: Review of the literature and current policy in the early childhood field'. Papers inwopa08/51, Innocenti Working Papers No. 2008/01, UN, New York, 2008.

[41] Gábos A. The chances of an integrated family policy in the European Union. [Egy egységes családpolitika kialakulásának esélye az Európai Unióban.] Esély 2004; 15: 3-31. [Hungarian]

(Szombati Ivett dr., Györ, Szent Imre út 26-28., 9024 e-mail: szombatiyvett@gmail.com)

A cikk a Creative Commons Attribution-NonCommercial 4.0 International License (https://creativecommons.org/licenses/by-nc/4.0) feltételei szerint publikált Open Access közlemény, melynek szellemében a cikk nem kereskedelmi célból bármilyen médiumban szabadon felhasználható, megosztható és újraközölhetö, feltéve, hogy az eredeti szerzỏ és a közlés helye, illetve a CC License linkje és az esetlegesen végrehajtott módositások feltüntetésre kerülnek. 